DOI https://doi.org/10.36059/978-966-397-194-0/99-131

\title{
THE METHODOLOGY OF THE MODELLING OF THE FRACTAL POETICAL MODEL OF THE WORLD (BASED ON THE BRITISH POETRY OF THE XIX ${ }^{\mathrm{TH}}$ CENTURY)
}

\section{Oksana Moskvichova}

INTRODUCTION

\begin{abstract}
To see a World in a grain of sand, And a Heaven in a wild flower, Hold Infinity in the palm of your hand,

And Eternity in an hour. (W. Blake "Auguries of Innocence", )
\end{abstract}

In the mathematics, in the computer science, in the fractal geometry, in the theory of systems, and in the synergetics 'the fractal' (from the Latin 'fractus' - 'to break, to destroy') - is identified as the object that is characterized by the fractional structure having the hierarchical level of the organization; as the endless geometrical figure every fragment of which is repeated in the reduced scale ${ }^{2}$. In the academic scientific world the leading role in the generation of the theory of fractals belongs to the mathematics because fractals have been identified by the mathematician Benoit B. Mandelbrot in his scientific research "The Fractal Geometry of Nature"3. Benoit B. Mandelbrot generated fractals by means of the mathematical and computer calculations and the researches of the coastline of Great Britain. Fractals have been investigated deeply in the mathematics but this term belongs also to the sphere of the synergetics, the science that comprises the physics and the mathematics, and has been integrated into the linguistics being the interdisciplinary direction of the scientific researches in the aspect of which are investigated processes of the transition from the chaos to the order and (in English)

${ }^{1}$ Blake W. (2019) The Selected Poems. London : Wordsworth Poetry Library.

${ }^{2}$ Demenok S. L. (2018) Prosto fraktal. [The Simple Fractal]. Sankt-Peterburg : Strata. (in Russian)

${ }^{3}$ Mandelbrot B. B. (1982) The Fractal Geometry of Nature. New York : W. H. Freemanand Company. (in English) 
vice versa in the open nonlinear spheres of the different nature ${ }^{4}$. In the article we are served by the dominant role of the exploration of the fractality in the mathematics because in the process of the constructing of the fractal poetical model of the world we rely on the postulates of the mathematical modelling of fractals.

The aim of the article is to describe the process of the modelling of the fractal poetical model of the world in the linguistic and the cognitive aspects on the basis of the British poetry of the XIX $-\mathrm{XXI}^{\text {st }}$ centuries.

The object of the scientific research is the fractal poetical model of the world in the British poetry of the XIX - XXI ${ }^{\text {st }}$ centuries. The subject the cognitive and the fractal potential of literary concepts ${ }^{5}$, conceptual tropes, frames and emergent conceptual blends as verbal means of the modelling of the fractal poetical model of the world on the basis of the British poetical texts of the romantic, the modern and the postmodern periods.

The material of the investigation is presented by the British poetry of the XIX $-\mathrm{XXI}^{\mathrm{st}}$ centuries in the total amount of 3628 poetical texts (4832 pages). For the illustration of the design of the fractal poetical model of the world have been chosen the brightest examples (490 poetical texts on 267 pages).

The methodology of the modelling of the fractal poetical model of the world is polydisciplinary conditioned by the combination of the interpretational, the textual, the descriptive, the semantic, the component, the linguistic, the stylistic, the cognitive, the poetical, the mathematical, the fractal, the geometrical methodology.

\section{The illumination of fractals in the modern scientific paradigm}

The founder of the theory of the fractality Benoit B. Mandelbrot has identified the term 'the fractal' from the Latin words 'frangere' ('to break') and 'fractus' ('ruptured, discrete, fractional'). The word is identical to the English 'fracture' ('the rapture') and 'fraction' ('the fraction'). Except the meaning 'fractional' (in words 'the fraction' and

${ }^{4}$ Demenok S. L. (2018) Superfraktal. [The Superfractal]. Sankt-Peterburg : Strata. (in Russian)

5 Nikonova V., Boyko Y. (2019) Gender-specific emotivity of Victorian female prose from a multidimensional perspective. In Lege artis. Language yesterday, today, tomorrow. Vol. IV (1), pp. 47-82. (in English) 
'the refraction') the word 'fractus' means 'the wrong-shaped'6. Thus, Benoit B. Mandelbrot has modeled the definition of the identified by him term 'the fractal' as for the algorithm and the association from the English 'FRACTionAL'. Even graphically Benoit $\mathrm{B}$. Mandelbrot has written the word 'FRACTAL' from 'FRACTionAL' by means of capital letters in the way the cognitive scientists write identified and verbalized concepts. The conceptual sphere in the field of the cognitive linguistics is graphically represented by the linguists in the similar way to the Circular Apollo Fractal (e.g., (Fig. 1)). Thus, we surmise the existence of the connection between the cognitive linguistics and the fractional mathematical theory in the graphical way.
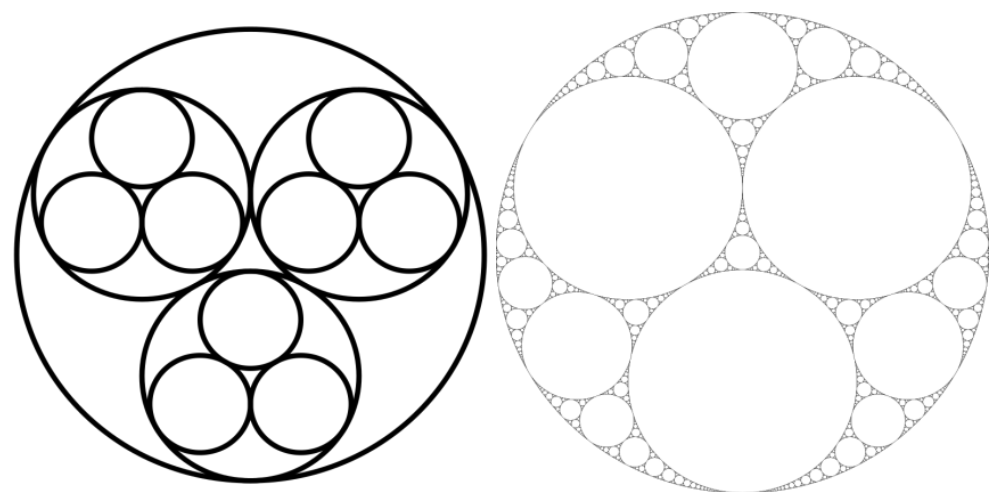

Fig. 1. The Circular Apollo Fractals

Fractals or the mathematical and the geometrical monsters have changed the mathematics of the end of the $\mathrm{XX}^{\text {th }}$ century and after their multidisciplinary integration into different scientific spheres lots of terms and forms have been identified by the scientists in the fractional and the mathematical way. Benoit B. Mandelbrot has summarized different types of fractals, has identified the ways of the fractional computer calculation that have been integrated into the modern fractional computer graphics (e.g., (Fig. 2; Fig. 3; Fig. 4) ${ }^{7}$.

${ }^{6}$ Demenok S. L. (2018) Prosto fraktal. [The Simple Fractal]. Sankt-Peterburg : Strata. (in Russian)

7 Mandelbrot B. B. (1982) The Fractal Geometry of Nature. New York : W. H. Freemanand Company. (in English) 

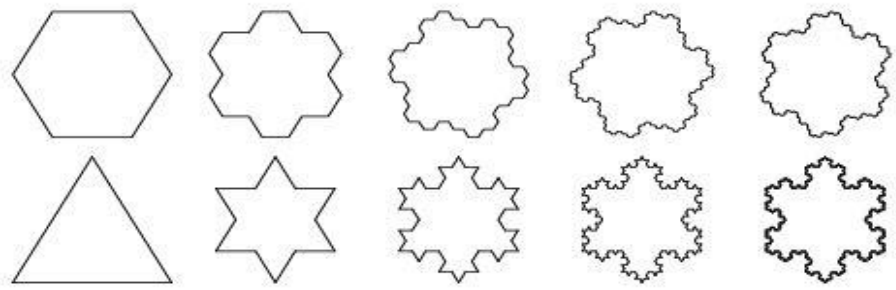

हूल हु हु
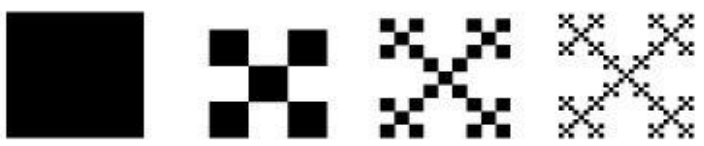

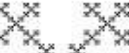

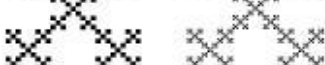
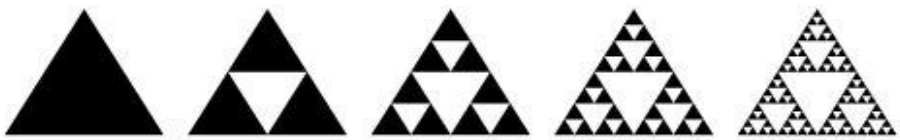

Fig. 2. Types of fractals
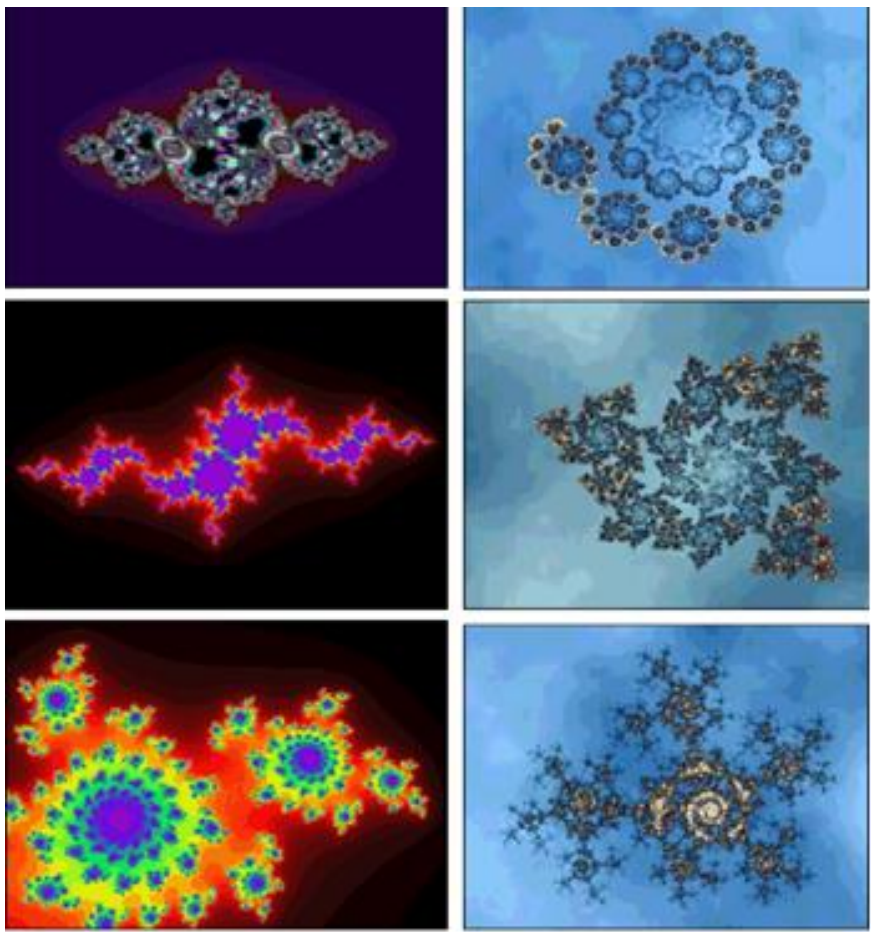

Fig. 3. Types of fractals in the computer graphics 


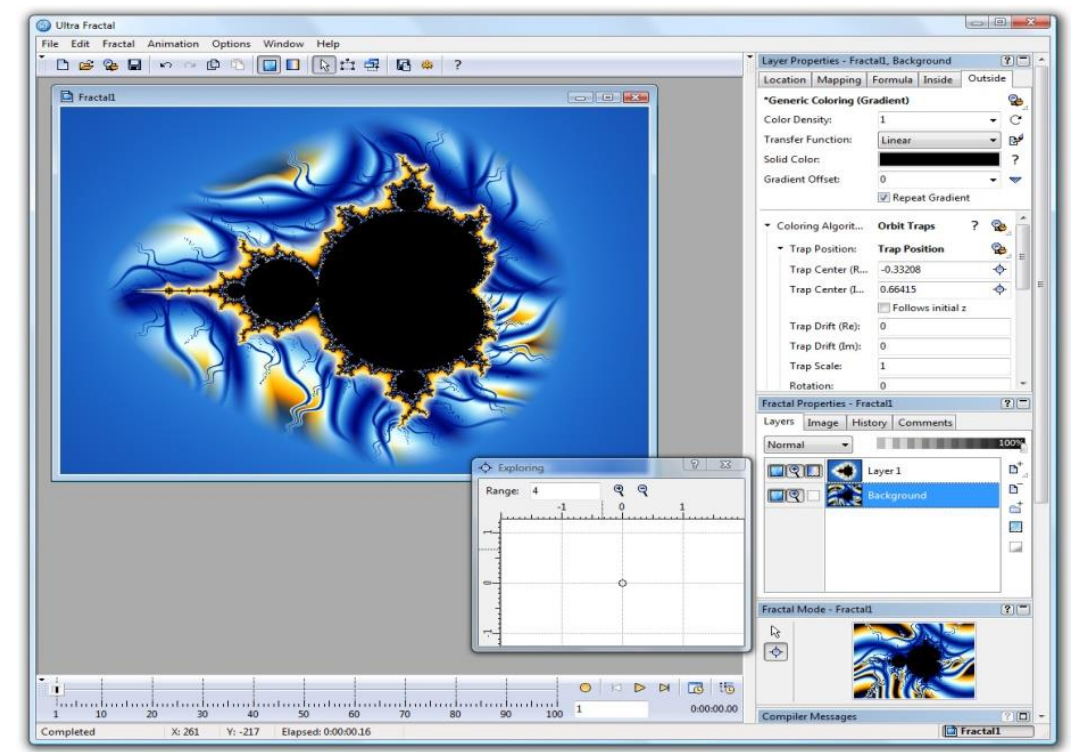

Fig. 4. The computer calculation of fractals in the computer graphics

Benoit B. Mandelbrot has stated that every self-similar fractal element is never-ending because structurally every fractal consists from the smallest or the fractional elements the modelling of which is ruled by the previous elements of the fractal. The fractal is the self-similar and the never-ending unity, the connection between elements of which is determined by the connection between all the elements of the fractal. The construction of the fractal is strict and mathematically determined because every small element of the fractal is the simplified version of the whole fractal. The process of the modelling of the fractal is ruled by the repeated repetition of the analogical mathematical operations - iterations. Fractal iterations are recursive, the final stage of the previous element of the fractal is the beginning of the new stage of the fractal modelling - the iterational fractal process. The fractal modelling is the endless process because fractals have the beginning but don't have the ending and the final stage of the modelling ${ }^{8}$.

${ }^{8}$ Demenok S. L. (2018) Superfraktal. [The Superfractal]. Sankt-Peterburg : Strata. (in Russian) 


\section{The modelling of the fractal poetical model of the world}

Extrapolating the methodology of the linguistic, the poetical, the cognitive analysises of the poetry and considering the results of the fractal modelling in the mathematics, in the fractal geometry, in the synergetics, in the theory of systems we propose the methodology of the modelling of the fractal poetical model of the world on the basis of the British poetry of the XIX $-\mathrm{XXI}^{\text {st }}$ centuries in the linguistic and the cognitive perspectives.

Thus, the fractal poetical model of the world is characterized by the complex structure, the starting point of it's constructing is the strange / the circular / the cyclic fractal attractor (from the Latin 'attrahere' - 'to attract'; from the English 'to attract') ' $^{9}$. The fractal attractor is the starting point of the fractal modelling that is stable and attracts to itself all the trajectory of the whole fractal system or the fractal model. Structurally, in the aspect of the fractal geometrical modelling, the fractal attractor comprises from the central node around which, in the spiral form, are pulverized trajectories of the fractal that never intersect and are concentrated around the central node of the attractor. The strange fractal attractor in the fractal modelling is the trajectory of the fractal orbit that makes possible the fractal modelling to get started in such a way: 'the central node of the strange fractal attractor $\rightarrow$ the cycle $\rightarrow$ the fractal' (e.g., (Fig. 5)):
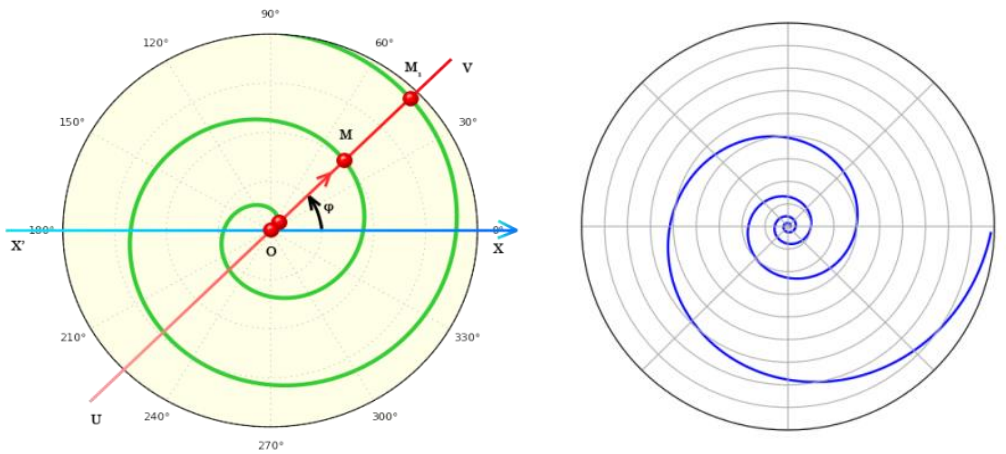

Fig. 5. The trajectory of the fractal modelling from the central node of the strange fractal attractor to the cycle and to the fractal

${ }^{9}$ Demenok S. L. (2018) Superfraktal. [The Superfractal]. Sankt-Peterburg : Strata. (in Russian) 
Integrating the theoretical aspects of the fractal modelling and taking into consideration the actuality of the term 'the strange fractal attractor' in the aspect of the fractal constructing while the modelling of the fractal poetical model of the world we propose to understand under the central node of the attractor the literary concept or literary concepts that are identified by us in the British poetry of the XIX $-\mathrm{XXI}^{\text {st }}$ centuries. The literary concept in the cognitive linguistics and the cognitive poetics is the basic element of the fractal conceptual model of the world that includes linguistic and extra-linguistic aspects determined by historical and cultural traditions of the romantic, the modern and the postmodern periods in Great Britain.

The central node of the fractal poetical model of the world is the literary concept / literary concepts. According to the trajectory of the orbit of the strange fractal attractor the dynamics of the fractal modelling of the poetical model of the world we outline in such an order: literary concepts $\rightarrow$ the basic conceptual tropes (the conceptual metaphor, the conceptual metonymy, the conceptual oxymoron, the conceptual metamorphosis $\left.{ }^{10}\right) \rightarrow$ the frame mode of the fractal poetical model of the world (frames) $\rightarrow$ the integrated mode of the fractal poetical model of the world (emergent conceptual blends).

The article is concentrated around the identification of the literary concepts and the basic conceptual tropes in the British poetry of the $\mathrm{XIX}-\mathrm{XXI}^{\mathrm{st}}$ centuries and the frame and the integrated modes of the fractal poetical model of the world will be represented in the next publications of the author of the article.

The deep nature of the fractal poetical model of the world is determined by it's complicated linguistic and cognitive aspects that are explained by the combination in the fractal poetical model of the world micro-segments (literary concepts), macro-segments (basic conceptual tropes), frames and the emergent conceptual blends in one fractal unity. We define the fractal poetical model of the world as the complex linguistic, cognitive and fractal construct that comprises from segments modelled according to the iterational and integrated methodology of the linguistic, the poetical, the cognitive analysises with the deployment into the fractal net of the conceptual senses filled with frames and conceptual blends.

10 Moskvichova O. A. (2015) Evoljucija metamorfozy $v$ anghlijsjkomu poetychnomu myslenni : monoghrafija. [The Evolution of Metamorphosis in the English Poetry : the Monograph]. Kherson : Ajlant. (in Ukrainian) 
In the cognitive linguistics has been proved that the fractal 'iteration' (from the Latin 'iteration' - 'to repeat') is the process of the multiple repetition of the analogous structure or the step as for the analogy with the previous repetitive operation. The fractal 'recursion' (from the Latin 'recursio' - 'the returning') - the process of the repetition according to the certain algorithm or the formula when the starting cycle is the result of the previous cycle. The fractal self-similarity is the fractal peculiarity of the whole fractal system in which the structural organization of an element is repeated completely or partially according to the structure of other elements of the whole fractal system ${ }^{11}$.

In the article we propose the fractal modelling of the fractal poetical model of the world based on the computer fractal modelling the fundamental fractal of which is the Mandelbrot Fractal. But our investigation is added by the linguistic and the cognitive aspects of the fractal poetical model of the world based on the results of the scientific research on the basis of the British poetry of the XIX $-\mathrm{XXI}^{\text {st }}$ centuries from the point of the cognitive linguistics and the cognitive poetics. In such a way our investigation is multidisciplinary or the subdisciplinary combining the fractal theory in the mathematics and in the fractal geometry integrated into the sphere of the cognitive linguistics and the cognitive poetics.

We have stated that the starting point of the modelling of the fractal poetical model of the world is the literary concept or literary concepts identified by us in the British poetry of the XIX $\mathrm{XXI}^{\text {st }}$ centuries. The hierarchy of the verbalized literary concepts is congregated by us into the micro-segment of the fractal poetical model of the world. We design the micro-segment of the fractal poetical model of the world on the basis of the graphic modelling of the Mandelbrot Fractal that consists from three concentric circles. The main circle of the mentioned fractal is the main cardioid and the additional circles are the copies of the main cardioid circle. The number of additional circles may be endless (e.g., (Fig. 6)):

11 Bystrov Ja. V. (2016) Bioghrafichnyj naratyv u linghvokoghnityvnomu vymiri (na materiali anghlomovnoji prozy XX - pochatku XXI stolitj) [The Biographical Narrative in the Linguistic and the Cognitive Aspects (on the basis of the English Prose of the $X X^{\text {th }}$ - the beginning of the XXI ${ }^{\text {st }}$ Centuries] : dys. ... d-ra fil. nauk : 10.02.04 / Kyjivsjkyj nac. linghvistychnyj un-t. Kyjiv. (in Ukrainian) 


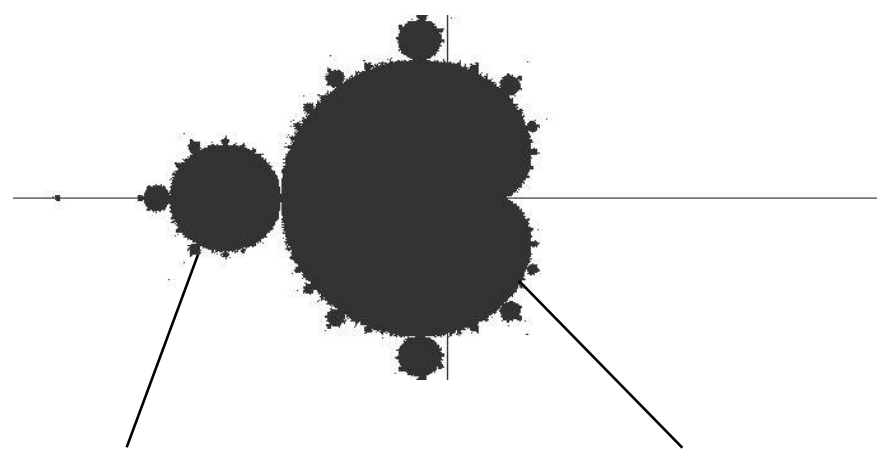

additional circles

the main cardioid circle

\section{Fig. 6. The graphic modelling and the structure of the Mandelbrot Fractal}

According to such a graphic design of the structure of the Mandelbrot Fractal we model the micro-segment of the fractal poetical model of the world that is impregnated by the identified by us literary concepts on the basis of the British poetry of the XIX $-\mathrm{XXI}^{\text {st }}$ centuries. The main cardioid circle of the micro-segment of the fractal poetical model of the world (1) is the presentive and the sensual and is impregnated by the aptly identified literary concepts in the British poetry of the XIX $-\mathrm{XXI}^{\text {st }}$ centuries. The first additional circle of the fractal micro-segment of the fractal poetical model of the world (2) is denominated by us the typology of the conceptual and the semantic approximations on the micro-level of the micro-segment and is nominated by us the imaginative and the associative circle. This circle we impregnate by the literary concepts containing the information of the associative type. The next additional circle (3) is the circle of the conceptual and the semantic deviations and is impregnated by rare literary concepts and is identified by us as the semantic circle (e.g., (Fig. 7)):

In the analogical way we design the macro-segment of the fractal poetical model of the world that is repleted by the reconstructed by us conceptual tropes (the conceptual metaphor, the conceptual metonymy, the conceptual oxymoron, the conceptual metamorphosis ${ }^{12}$ (e.g., (Fig. 8)):

12 Moskvichova O. A. (2015) Evoljucija metamorfozy $v$ anghlijsjkomu poetychnomu myslenni : monoghrafija. [The Evolution of Metamorphosis in the English Poetry : the Monograph]. Kherson : Ajlant. (in Ukrainian) 


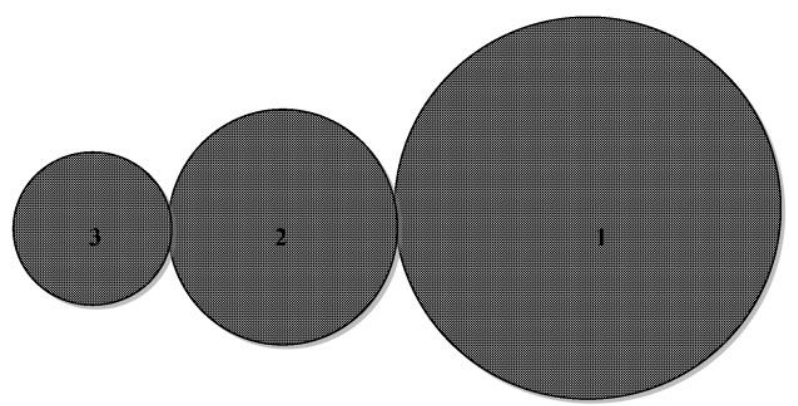

Fig. 7. The fractal modelling of the micro-segments of the fractal poetical model of the world the presentive and the sensual microsegment of the typology of the fractal iterations of the self-similar literary concepts; $\mathbf{2}$ - the conceptual and the semantic micro-segment of the typology of the conceptual and the semantic approximations; 3 - the semantic micro-segment of the typology of the conceptual and the semantic deviations)

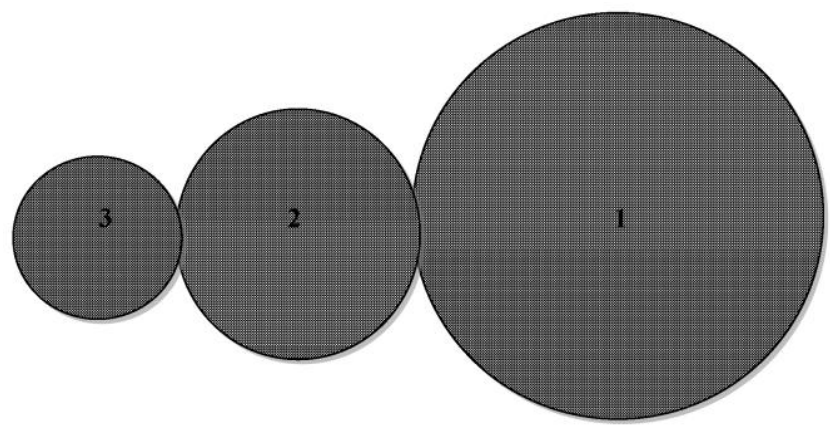

Fig. 8. The fractal modelling of the macro-segments of the fractal poetical model of the world

(1- the presentive and the sensual macro-segment of the typology of the fractal iterations of the self-similar conceptual tropes; 2 - the conceptual and the semantic macro-segment of the typology of the conceptual and the semantic approximations; 3 - the semantic macrosegment of the typology of the conceptual and the semantic deviations)

As we have been mentioned the fractal recursion is the process when the previous step of the fractal modelling is the starting point of the design of the next fractal step. The Mandelbrot Fractal in the fractal 
geometry is the starting point or the reservoir for the further fractal modelling the variety of which is identified in mathematics and the fractal geometry (e.g., (Fig. 9; Fig. 10)):

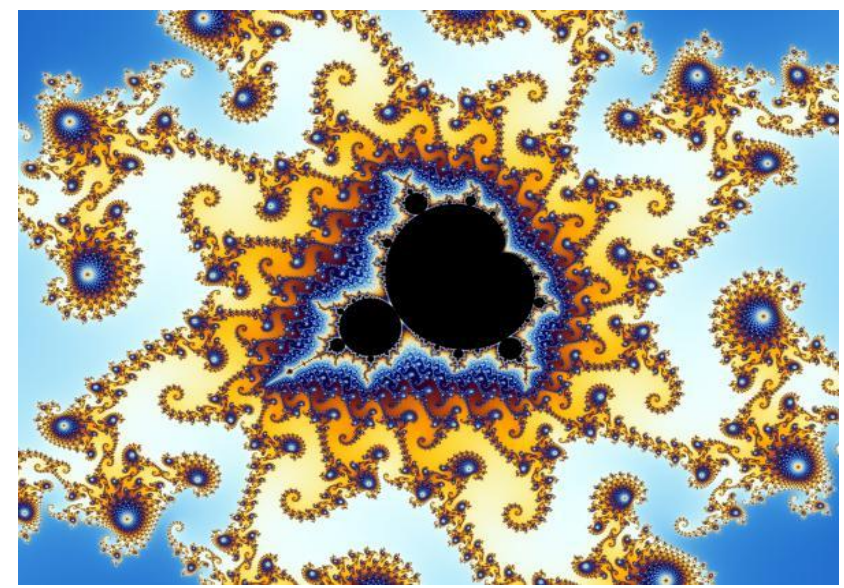

Fig. 9. The computer design of various fractals from the reservoir of the Mandelbrot Fractal

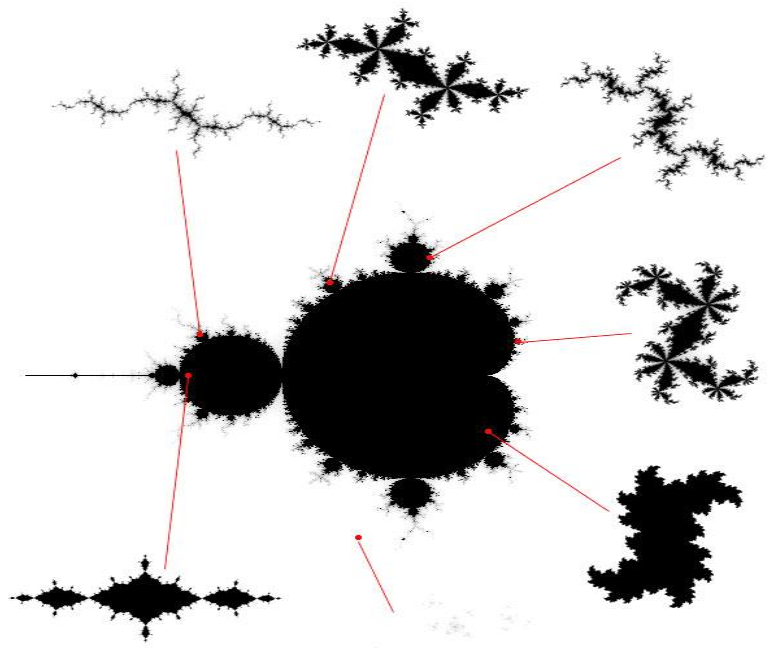

Fig. 10. The modification of various fractals from the reservoir of the Mandelbrot Fractal 
In our scientific investigation the micro-segment of the fractal poetical model of the world is transformed into the segment of the conceptual senses of the frame mode fulfilled by frames. The macrosegment of the fractal poetical model of the world is transformed into the net of the conceptual senses of the integrated mode fulfilled by emergent conceptual blends. Frames and conceptual blends are modelled according to linguistic and cognitive operations and procedures existing in the cognitive linguistics and the cognitive poetics and will be presented by us in the next articles (e.g., (Fig. 11)):

The micro-segment

of the fractal poetical

model of the world

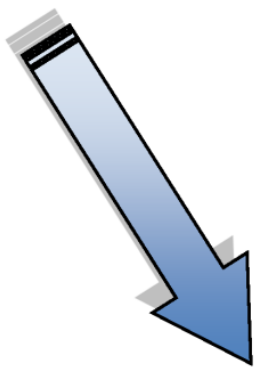

The frame mode

of the fractal poetical model of the world (frames) world (conceptual blends)
The macro-segment of the fractal poetical model of the world

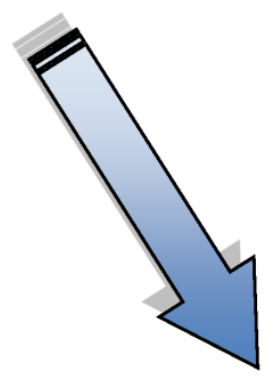

The integrated mode of the fractal poetical model of the

\section{Fig. 11. The transformation of micro- and macro-segments of the fractal poetical model of the world into integrated modes}

Graphically integrated modes will be designed by us as various types of fractals. Thus frames will be modelled as the Fractal 'Snowflake', conceptual blends - as the Fractal 'Square' (e.g., (Fig. 12)): 

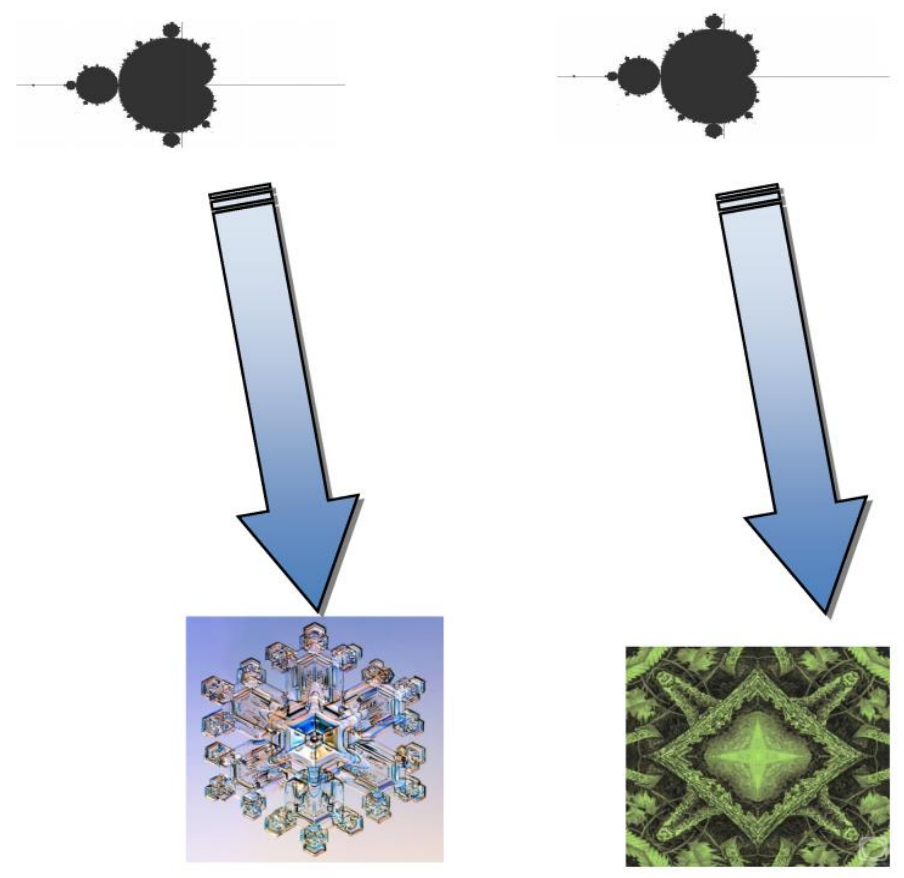

Fig. 12. The graphic transformation of micro- and macro-segments of the fractal poetical model of the world into integrated modes

The fractal iteration in the process of the modelling of the fractal poetical model of the world is characterized by us as main procedures of the identification and the reconstruction of literary concepts and conceptual tropes existing in the cognitive linguistics and in the cognitive poetics. And the whole fractal poetical model of the world, consisting from micro- and macrosegments, integrated frames and conceptual blends modes will be graphically modelled as the Dragon Fractal of HarterHeighway or the Fractal Julia and will be presented in the next scientific publications of the author (e.g., (Fig. 13)):

In the result of the investigation of the realization of the designed fractal poetical model of the world in the British poetry of the XIX $\mathrm{XXI}^{\text {st }}$ centuries we propose the summarizing results that form the basis for the construction of the micro- and the macro-segments of the fractal poetical model of the world. The material of the scientific doctoral research of the author in the doctoral dissertation on the title "The fractal 
poetical model of the world in the linguistic and the cognitive survey (on the material of the British poetry of the XIX $-\mathrm{XXI}^{\text {st }}$ centuries) includes the British poetry of the mentioned centuries in the total amount of 3628 poetical texts (4832 pages). From the analyzed poetry the author of the article has chosen the brightest examples (490 poetical texts (267 pages)). The results of the investigation are illustrated by the author in the doctoral dissertation on the basis of 230 poetical texts. In the article we represent the summarizing results in tables because the whole amount of the poetical texts analyzed in the dissertation comprises 93 pages and can't be illustrated in the article.

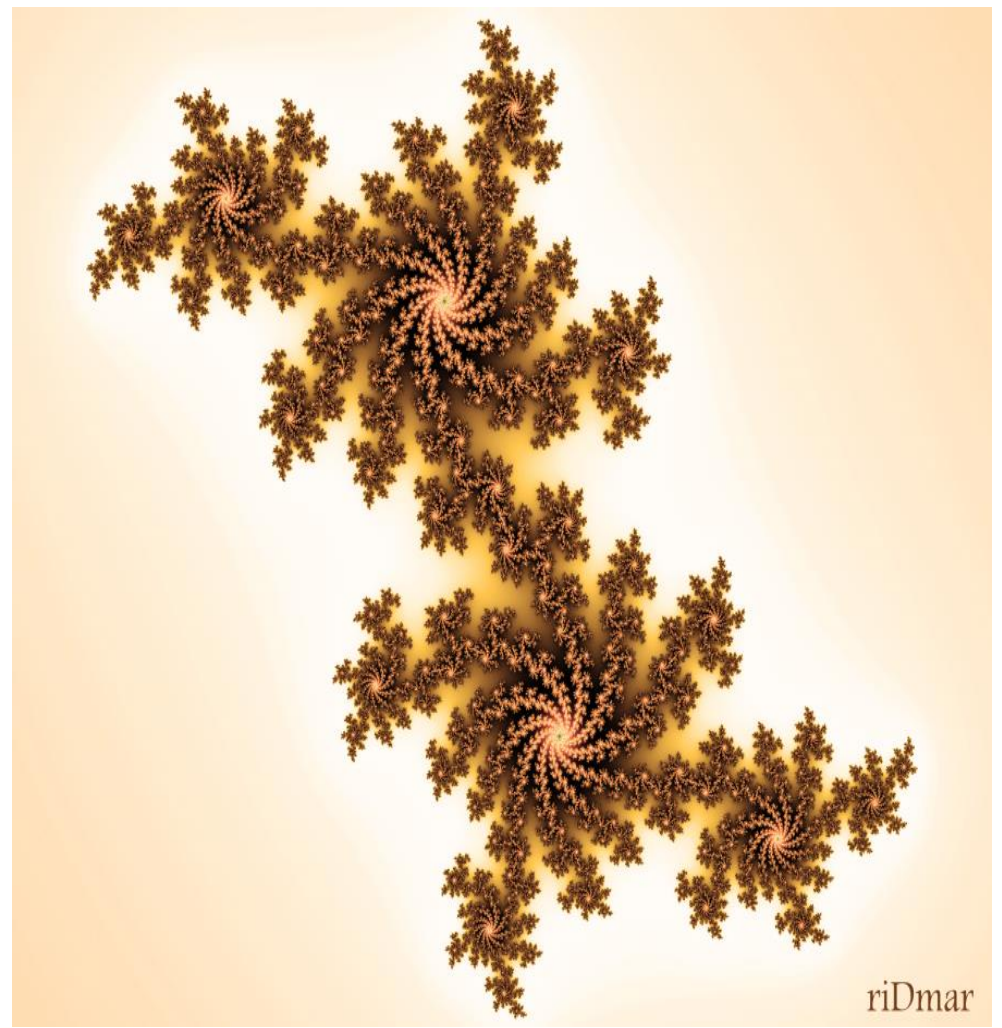

Fig. 13. The Dragon Fractal of Harter-Heighway or the Fractal Julia

As we have mentioned the microsegment of the fractal poetical model of the world is represented by the identified literary concepts in the 
British poetry of the XIX $-\mathrm{XXI}^{\text {st }}$ centuries. We have stated that microand macrosegments of the fractal poetical model of the world are designed by us on the basis of the Mandelbrot Fractal. Both micro- and macrosegments consist of tree circles, such as:

- the first main cardioid circle (the presentive and the sensual) - (1);

- the second additional circle (the conceptual and the semantic approximations) - (2);

- the third additional circle (the semantic deviations) - (3).

Graphically both micro- and macro segments we design according to the model of the Mandelbrot Fractal (e.g., (Fig. 14)):

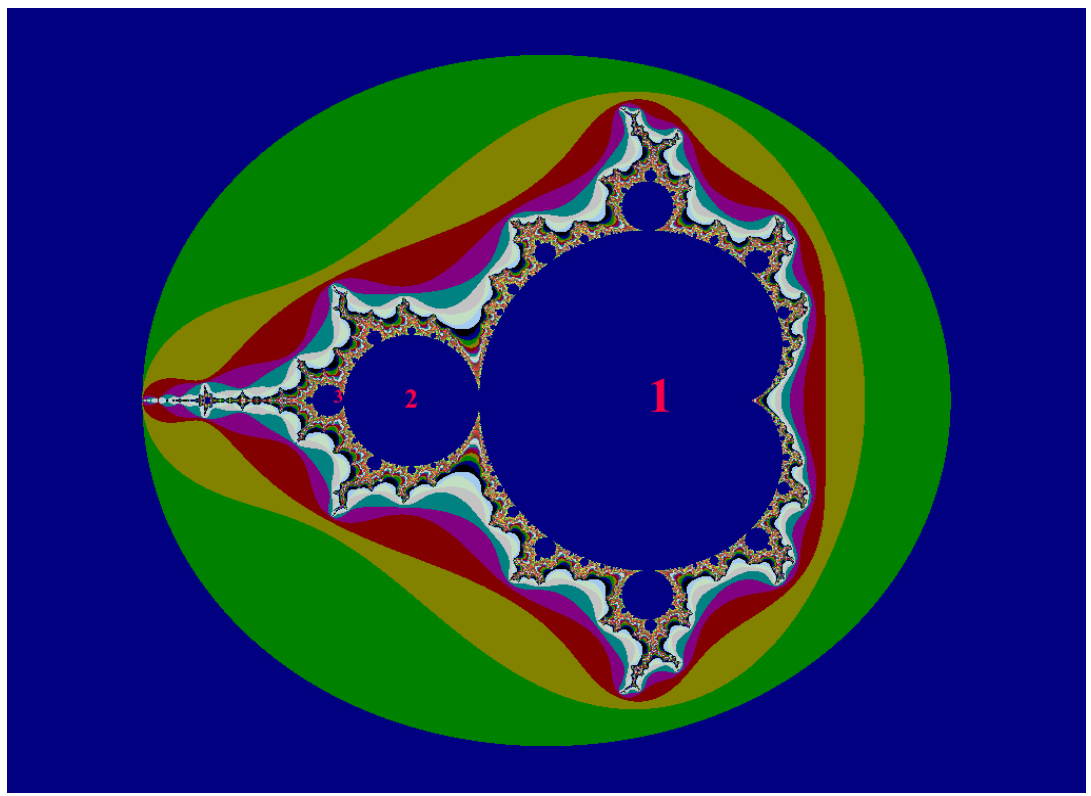

Fig. 14. The graphic design of micro- and macrosegments of the fractal poetical model of the world

The hierarchy of the literary concepts identified in the British poetry of the romantic period that fill the first main circle of the microsegment of the fractal poetical model of the world are presented in the following table (numbers $1-4$ ). The second additional circle is filled by the literary concepts (numbers $5-34$ ). The third additional circle is filled by the literary concepts (numbers 35 - 79) (Table 1): 
Table 1

Literary concepts identified in the British poetical texts of the romantic period

\begin{tabular}{|c|l|c|}
\hline \multicolumn{2}{|c|}{ The hierarchy of the literary concepts } & $\begin{array}{c}\text { The total amount of } \\
\text { the realization }(\%)\end{array}$ \\
\hline $\mathbf{1}$ & \multicolumn{1}{|c|}{$\mathbf{3}$} \\
\hline 1. & LIFE & $45(15 \%)$ \\
\hline 2. & DEATH & $40(13 \%)$ \\
\hline 3. & LOVE & $32(10 \%)$ \\
\hline 4. & PERSON / PERSONALITY & $22(7 \%)$ \\
\hline 5. & GOD & $16(5 \%)$ \\
\hline 6. & TIME & $16(5 \%)$ \\
\hline 7. & NATURE & $10(3 \%)$ \\
\hline 8. & JOY & $7(2 \%)$ \\
\hline 9. & REVIVAL & $6(1,9 \%)$ \\
\hline 10. & HAPPINESS & $5(1,6 \%)$ \\
\hline 11. & HOPE & $5(1,6 \%)$ \\
\hline 12. & FREEDOM & $5(1,6 \%)$ \\
\hline 13. & DREAM & $4(1,3 \%)$ \\
\hline 14. & FRIEND & $3(0,9 \%)$ \\
\hline 15. & SLEEP & $3(0,9 \%)$ \\
\hline 16. & SOUL & $3(0,9 \%)$ \\
\hline 17. & WOMAN & $3(0,9 \%)$ \\
\hline 18. & HEAVEN & $3(0,9 \%)$ \\
\hline 19. & IDENTITY & $2(0,6 \%)$ \\
\hline 20. & INHUMANITY & $2(0,6 \%)$ \\
\hline 21. & FATE & $2(0,6 \%)$ \\
\hline 22. & PLEASURE & $2(0,6 \%)$ \\
\hline 23. & AGE & $2(0,6 \%)$ \\
\hline 24. & SELF & $2(0,6 \%)$ \\
\hline 25. & DAY & $2(0,6 \%)$ \\
\hline 26. & JOURNEY & $2(0,6 \%)$ \\
\hline 27. & FRIENDSHIP & $2(0,6 \%)$ \\
\hline 28. & MIRACLE & $2(0,6 \%)$ \\
\hline 29. & BETRAYAL & $2(0,6 \%)$ \\
\hline 30. & FAME & $2(0,6 \%)$ \\
\hline 31. & MYTHOLOGY & $2(0,6 \%)$ \\
\hline 32. & WORLD & \\
\hline & & $2 \%)$ \\
\hline
\end{tabular}


Continuation of table 1

\begin{tabular}{|c|c|c|}
\hline $\mathbf{1}$ & 2 & 3 \\
\hline 33. & INSPIRATION & $2(0,6 \%)$ \\
\hline 34. & PEOPLE & $2(0,6 \%)$ \\
\hline 35. & COLOUR & $1(0,3 \%)$ \\
\hline 36. & MOTHER & $1(0,3 \%)$ \\
\hline 37. & CHILD & $1(0,3 \%)$ \\
\hline 38. & HEART & $1(0,3 \%)$ \\
\hline 39. & THOUGHT & $1(0,3 \%)$ \\
\hline 40. & ENGLAND & $1(0,3 \%)$ \\
\hline 41. & GRIEF & $1(0,3 \%)$ \\
\hline 42. & TRINITY & $1(0,3 \%)$ \\
\hline 43. & PAIN & $1(0,3 \%)$ \\
\hline 44. & WILINESS & $1(0,3 \%)$ \\
\hline 45. & VALUE & $1(0,3 \%)$ \\
\hline 46. & HOLINESS & $1(0,3 \%)$ \\
\hline 47. & HEALTH & $1(0,3 \%)$ \\
\hline 48. & CONTAINER & $1(0,3 \%)$ \\
\hline 49. & CREATION & $1(0,3 \%)$ \\
\hline 50. & SIN & $1(0,3 \%)$ \\
\hline 51. & DOG & $1(0,3 \%)$ \\
\hline 52. & RESURRECTION & $1(0,3 \%)$ \\
\hline 53. & IMMORTALITY & $1(0,3 \%)$ \\
\hline 54. & POWER & $1(0,3 \%)$ \\
\hline 55. & POISON & $1(0,3 \%)$ \\
\hline 56. & MUTABILITY & $1(0,3 \%)$ \\
\hline 57. & ART & $1(0,3 \%)$ \\
\hline 58. & CITY & $1(0,3 \%)$ \\
\hline 59. & DECORATION & $1(0,3 \%)$ \\
\hline 60. & NIGHT & $1(0,3 \%)$ \\
\hline 61. & MUSIC & $1(0,3 \%)$ \\
\hline 62. & NUMBER & $1(0,3 \%)$ \\
\hline 63. & EGO & $1(0,3 \%)$ \\
\hline 64. & MELODY & $1(0,3 \%)$ \\
\hline 65. & AMBITION & $1(0,3 \%)$ \\
\hline 66. & WORD & $1(0,3 \%)$ \\
\hline 67. & LIGHT & $1(0,3 \%)$ \\
\hline 68. & FEELINGS & $1(0,3 \%)$ \\
\hline
\end{tabular}


End of table 1

\begin{tabular}{|c|c|c|}
\hline 1 & 2 & 3 \\
\hline 69. & SILENCE & $1(0,3 \%)$ \\
\hline 70 . & MOTION & $1(0,3 \%)$ \\
\hline 71. & HUMAN BEING & $1(0,3 \%)$ \\
\hline 72. & FEAR & $1(0,3 \%)$ \\
\hline 73. & TRUTH & $1(0,3 \%)$ \\
\hline 74. & BURDEN & $1(0,3 \%)$ \\
\hline 75 . & MIND & $1(0,3 \%)$ \\
\hline 76. & WEALTH & $1(0,3 \%)$ \\
\hline 77. & PLAY & $1(0,3 \%)$ \\
\hline 78. & POETRY & $1(0,3 \%)$ \\
\hline 79. & FLOWER & $1(0,3 \%)$ \\
\hline & \multicolumn{2}{|c|}{$\begin{array}{c}\text { The total amount of the literary concepts }-305(100 \%) \text {. } \\
\text { Numbers } 1-4-139(45 \%) \text {. } \\
\text { Numbers } 5-34-121(40 \%) \text {. } \\
\text { Numbers } 35-79-45(15 \%) .\end{array}$} \\
\hline
\end{tabular}

The hierarchy of the conceptual metaphors identified in the British poetry of the romantic period that fill the first main circle of the macrosegment of the fractal poetical model of the world are presented in the following table (numbers 1-2). The second additional circle is filled by the conceptual metaphors (numbers $3-18$ ). The third additional circle is filled by the conceptual metaphors (numbers 19-148) (Table 2):

Table 2

Conceptual metaphors reconstructed in the British poetical texts of the romantic period

\begin{tabular}{|c|l|c|}
\hline \multicolumn{2}{|c|}{$\begin{array}{c}\text { The hierarchy of the conceptual } \\
\text { metaphors }\end{array}$} & $\begin{array}{c}\text { The total amount of the } \\
\text { realization }(\%)\end{array}$ \\
\hline $\mathbf{1}$ & \multicolumn{1}{|c|}{$\mathbf{2}$} & $\mathbf{3}$ \\
\hline 1. & LIFE IS A JOURNEY & $7(4 \%)$ \\
\hline 2. & GOD IS UP & $6(3 \%)$ \\
\hline 3 & LIFE IS A RACE & $5(2,7 \%)$ \\
\hline 4. & DEATH IS SLEEP & $4(2 \%)$ \\
\hline 5. & LIFE IS A DREAM & $3(1,6 \%)$ \\
\hline 6. & TIME IS A MOTION & $3(1,6 \%)$ \\
\hline 7. & $\begin{array}{l}\text { LOVE IS A HUMAN BEING } \\
\text { (A PERSON) }\end{array}$ & $3(1,6 \%)$ \\
\hline
\end{tabular}


Continuation of table 2

\begin{tabular}{|c|c|c|}
\hline 1 & 2 & $\mathbf{3}$ \\
\hline 8. & LIFE IS WOE & $2(1 \%)$ \\
\hline 9. & GOD IS LOVE & $2(1 \%)$ \\
\hline 10. & $\begin{array}{l}\text { DEATH IS THE END OF A } \\
\text { JOURNEY }\end{array}$ & $2(1 \%)$ \\
\hline 11. & LOVE IS SLEEP & $2(1 \%)$ \\
\hline 12. & BEAUTY IS A LIVING BEING & $2(1 \%)$ \\
\hline 13. & LOVE IS THE POWER & $2(1 \%)$ \\
\hline 14. & NATURE IS A TEACHER & $2(1 \%)$ \\
\hline 15. & LIFE IS A CHANGE & $2(1 \%)$ \\
\hline 16. & DEATH IS LOVE & $2(1 \%)$ \\
\hline 17. & $\begin{array}{lcr}\text { LIFE IS A } & \text { JOURNEY } \\
\text { THROUGH TIME } & \\
\end{array}$ & $2(1 \%)$ \\
\hline 18. & LIFE IS STRUGGLE & $2(1 \%)$ \\
\hline 19. & PEOPLE ARE ANIMALS & $1(0,5 \%)$ \\
\hline 20. & DEATH IS THE FRIEND & $1(0,5 \%)$ \\
\hline 21. & $\begin{array}{l}\text { THE FATE OF A PERSON IS } \\
\text { THE RURAL SHADE }\end{array}$ & $1(0,5 \%)$ \\
\hline 22. & $\begin{array}{l}\text { THE FATE OF A PERSON IS } \\
\text { THE OCEAN }\end{array}$ & $1(0,5 \%)$ \\
\hline 23. & LIFE IS A PLEASURE & $1(0,5 \%)$ \\
\hline 24. & PEOPLE ARE PLANTS & $1(0,5 \%)$ \\
\hline 25. & A PERSON IS A STRANGER & $1(0,5 \%)$ \\
\hline 26. & LIFE IS DEATH & $1(0,5 \%)$ \\
\hline 27. & DEATH IS REVIVAL & $1(0,5 \%)$ \\
\hline 28. & EMOTIONS ARE NATURE & $1(0,5 \%)$ \\
\hline 29. & $\begin{array}{l}\text { LIFE IS A DAY, HAPPINESS IS } \\
\text { A NAME (A PERSON OR A } \\
\text { WORD) }\end{array}$ & $1(0,5 \%)$ \\
\hline 30. & $\begin{array}{lcr}\text { AMBITION IS A } & \text { METEOR- } \\
\text { GLEAM (A LIGHT) } & \\
\end{array}$ & $1(0,5 \%)$ \\
\hline 31. & FAME IS A DREAM & $1(0,5 \%)$ \\
\hline 32. & LOVE IS A DREAM & $1(0,5 \%)$ \\
\hline 33. & JOY IS LIFE & $1(0,5 \%)$ \\
\hline 34. & PLEASURE IS LIFE & $1(0,5 \%)$ \\
\hline 35. & EMOTIONS ARE LIFE & $1(0,5 \%)$ \\
\hline 36. & LIFE IS A BURDEN & $1(0,5 \%)$ \\
\hline 37. & TIME IS MOVEMENT & $1(0,5 \%)$ \\
\hline
\end{tabular}


Continuation of table 2

\begin{tabular}{|c|c|c|}
\hline 1 & 2 & 3 \\
\hline 38. & LOVE IS TRUE & $1(0,5 \%)$ \\
\hline 39. & MIND IS WEALTH & $1(0,5 \%)$ \\
\hline 40. & FRIENDSHIP IS A GIFT & $1(0,5 \%)$ \\
\hline 41. & LIFE IS A MORNING & $1(0,5 \%)$ \\
\hline 42. & LIFE IS A PLAY & $1(0,5 \%)$ \\
\hline 43. & GOD IS THE HEALER & $1(0,5 \%)$ \\
\hline 44. & 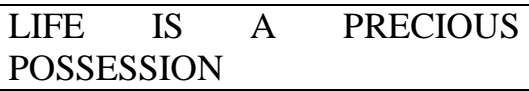 & $1(0,5 \%)$ \\
\hline 45. & TIME IS A DESTROYER & $1(0,5 \%)$ \\
\hline 46. & A PERSON IS AN ANGEL & $1(0,5 \%)$ \\
\hline 47. & PERSON IS A CONTAINER & $1(0,5 \%)$ \\
\hline 48. & LOVE IS IMMORTAL & $1(0,5 \%)$ \\
\hline 49. & FATE IS DARK & $1(0,5 \%)$ \\
\hline 50. & PEOPLE ARE CLOUDS & $1(0,5 \%)$ \\
\hline 51. & DREAM IS THE POWER & $1(0,5 \%)$ \\
\hline 52. & SLEEP IS POISON & $1(0,5 \%)$ \\
\hline 53. & MUTABILITY IS JOY & $1(0,5 \%)$ \\
\hline 54. & MUTABILITY IS SORROW & $1(0,5 \%)$ \\
\hline 55. & DEATH IS MILD & $1(0,5 \%)$ \\
\hline 56. & A CITY IS THE CRADLE & $1(0,5 \%)$ \\
\hline 57. & A CITY IS THE GRAVE & $1(0,5 \%)$ \\
\hline 58. & DEATH IS NIGHT & $1(0,5 \%)$ \\
\hline 59. & MUSIC IS THE LIVING BEING & $1(0,5 \%)$ \\
\hline 60. & LIFE IS UP & $1(0,5 \%)$ \\
\hline 61. & LIFE IS A RAINBOW & $1(0,5 \%)$ \\
\hline 62. & GOD IS THE CHILD & $1(0,5 \%)$ \\
\hline 63. & LIFE IS PIETY & $1(0,5 \%)$ \\
\hline 64. & A BRITON IS A SUBJECT & $1(0,5 \%)$ \\
\hline 65. & $\begin{array}{l}\text { PEOPLE ARE CREATURES OF } \\
\text { A WINTER'S DAY }\end{array}$ & $1(0,5 \%)$ \\
\hline 66. & LOVE IS A TEACHER & $1(0,5 \%)$ \\
\hline 67. & LOVE IS DEATH & $1(0,5 \%)$ \\
\hline 65. & LOVE IS GRAVE & $1(0,5 \%)$ \\
\hline 68. & LOVE IS PAIN & $1(0,5 \%)$ \\
\hline 69. & A PERSON IS A STATUE & $1(0,5 \%)$ \\
\hline 70. & LOVE IS A FOUNTAIN & $1(0,5 \%)$ \\
\hline
\end{tabular}


Continuation of table 2

\begin{tabular}{|c|c|c|}
\hline 1 & $\mathbf{2}$ & $\mathbf{3}$ \\
\hline 71. & NATURE IS THE CREATOR & $1(0,5 \%)$ \\
\hline 72. & $\begin{array}{llll}\text { THE LIFE OF } & \text { A } & \text { HUMAN } \\
\text { BEING IS A DAY } & & \\
\end{array}$ & $1(0,5 \%)$ \\
\hline 73. & THE LIFE IS THE MYSTERY & $1(0,5 \%)$ \\
\hline 74. & $\begin{array}{l}\text { A WOMAN IS A PHANTOM OF } \\
\text { DELIGHT / A LOVELY } \\
\text { APPARITITION / A MOMENT'S } \\
\text { ORNAMENT / A DANCING } \\
\text { SHAPE / AN IMAGE / A } \\
\text { CREATURE / A BEING / A } \\
\text { TRAVELLER BETWEEN LIFE } \\
\text { AND DEATH / AN ANGELIC } \\
\text { LIGHT }\end{array}$ & $1(0,5 \%)$ \\
\hline 75. & DEATH IS REST & $1(0,5 \%)$ \\
\hline 76. & HEART IS A CONTAINER & $1(0,5 \%)$ \\
\hline 77. & SOUL IS THE DARKNESS & $1(0,5 \%)$ \\
\hline 78. & LIFE IS SEA & $1(0,5 \%)$ \\
\hline 79. & TIME IS A LIVING BEING & $1(0,5 \%)$ \\
\hline 80. & HOPE IS A LIVING BEING & $1(0,5 \%)$ \\
\hline 81. & TIME IS HOPE & $1(0,5 \%)$ \\
\hline 82. & $\begin{array}{l}\text { TEARS ARE THE LIGHT OF } \\
\text { GLADNESS }\end{array}$ & $1(0,5 \%)$ \\
\hline 83. & WORDS ARE GOLD & $1(0,5 \%)$ \\
\hline 84. & A PERSON IS A NIGHTINGALE & $1(0,5 \%)$ \\
\hline 85. & JOY IS THE MASK & $1(0,5 \%)$ \\
\hline 86. & LIFE IS A CAVERN & $1(0,5 \%)$ \\
\hline 87. & LIFE IS A GLIMMER & $1(0,5 \%)$ \\
\hline 88. & A PERSON IS THE SPIRIT & $1(0,5 \%)$ \\
\hline 89. & A PERSON IS A SOUL & $1(0,5 \%)$ \\
\hline 90. & $\begin{array}{l}\text { HEART IS A CONTAINER } \\
\text { FULL OF SWEET IMAGES }\end{array}$ & $1(0,5 \%)$ \\
\hline 91. & LIFE IS A GAME & $1(0,5 \%)$ \\
\hline 92. & LIFE IS A VALUE & $1(0,5 \%)$ \\
\hline 93. & THE WORLD IS THE WHEEL & $1(0,5 \%)$ \\
\hline 94. & FREEDOM IS UP & $1(0,5 \%)$ \\
\hline 95. & HEAVEN IS UP & $1(0,5 \%)$ \\
\hline 96. & LIFE IS A DAY & $1(0,5 \%)$ \\
\hline
\end{tabular}


Continuation of table 2

\begin{tabular}{|c|c|c|}
\hline 1 & 2 & 3 \\
\hline 97. & DEATH IS DOWN & $1(0,5 \%)$ \\
\hline 98. & $\begin{array}{l}\text { LIFE IS A FLOWER / LIFE IS } \\
\text { A ROSE }\end{array}$ & $1(0,5 \%)$ \\
\hline 99. & LIFE IS AN ILLUSION & $1(0,5 \%)$ \\
\hline 100. & SOUL IS A SHIP & $1(0,5 \%)$ \\
\hline 101. & $\begin{array}{l}\text { A WOMAN (A PERSON) IS A } \\
\text { LIGHT }\end{array}$ & $1(0,5 \%)$ \\
\hline 102. & GOD IS A LIGHT & $1(0,5 \%)$ \\
\hline 103. & $\begin{array}{lccc}\text { LIFE } & \text { IS } & \text { A } & \text { JOURNEY } \\
\text { THRUOGH TIME } & \end{array}$ & $1(0,5 \%)$ \\
\hline 104. & $\begin{array}{llll}\text { LOVE } & \text { IS } & \text { A } & \text { MAGNETIC } \\
\text { FORSE } & & & \end{array}$ & $1(0,5 \%)$ \\
\hline 105. & DEATH IS LIGHT & $1(0,5 \%)$ \\
\hline 106. & HAPPINESS IS ENGLAND & $1(0,5 \%)$ \\
\hline 107. & DEATH IS PAIN & $1(0,5 \%)$ \\
\hline 108. & LIFE IS TRINITY & $1(0,5 \%)$ \\
\hline 109. & JOY IS LIGHT & $1(0,5 \%)$ \\
\hline 110. & LIFE IS A FROST & $1(0,5 \%)$ \\
\hline 111. & LOVE IS LIGHT & $1(0,5 \%)$ \\
\hline 112. & LOVE IS A TOMB & $1(0,5 \%)$ \\
\hline 113. & JOY IS HAPPINESS & $1(0,5 \%)$ \\
\hline 114. & GOD IS LIGHT & $1(0,5 \%)$ \\
\hline 115. & $\begin{array}{l}\text { DREAMS ARE STREAMS OF } \\
\text { SHADOWS }\end{array}$ & $1(0,5 \%)$ \\
\hline 116. & LOVE IS BONDAGE & $1(0,5 \%)$ \\
\hline 117. & LOVE IS A HEAVEN & $1(0,5 \%)$ \\
\hline 118. & LOVE IS A HELL & $1(0,5 \%)$ \\
\hline 119. & LOVE IS A CRIME & $1(0,5 \%)$ \\
\hline 120. & DEATH IS THE GARMENT & $1(0,5 \%)$ \\
\hline 121. & HAPPINESS IS WOE & $1(0,5 \%)$ \\
\hline 122. & HEAVEN IS MISERY & $1(0,5 \%)$ \\
\hline 123. & LOVE IS A WIND & $1(0,5 \%)$ \\
\hline 124. & DEATH IS THE BLOSSOM & $1(0,5 \%)$ \\
\hline 125. & LOVE IS A SIN & $1(0,5 \%)$ \\
\hline 126. & $\begin{array}{llll}\text { DEATH } & \text { IS } & \text { THE } & \text { LIVING } \\
\text { BEING } & & & \\
\end{array}$ & $1(0,5 \%)$ \\
\hline
\end{tabular}


End of table 2

\begin{tabular}{|c|c|c|}
\hline 1 & 2 & $\mathbf{3}$ \\
\hline 127. & LOVE IS DESIRE & $1(0,5 \%)$ \\
\hline 128. & LOVE IS A FLAME & $1(0,5 \%)$ \\
\hline 129. & $\begin{array}{l}\text { THE WORLD IS A } \\
\text { CONTAINER }\end{array}$ & $1(0,5 \%)$ \\
\hline 130. & HOPE IS A DREAM & $1(0,5 \%)$ \\
\hline 131. & LOVE IS A UNITY & $1(0,5 \%)$ \\
\hline 132. & LOVE IS A GRIEF & $1(0,5 \%)$ \\
\hline 133. & TIME IS THE RIVER & $(0,5 \%) 1$ \\
\hline 134. & LIFE IS A CYCLE & $1(0,5 \%)$ \\
\hline 135. & LOVE IS A CONTAINER & $1(0,5 \%)$ \\
\hline 136. & DREAMS ARE THE SALE & $1(0,5 \%)$ \\
\hline 137. & LIFE IS DEATH & $1(0,5 \%)$ \\
\hline 138. & DREAM IS A PRIZE & $1(0,5 \%)$ \\
\hline 139. & JOY IS HEAVEN & $1(0,5 \%)$ \\
\hline 140. & HOPE IS LIGHT & $1(0,5 \%)$ \\
\hline 141. & DEATH IS COLD & $1(0,5 \%)$ \\
\hline 142. & TIME IS A SEASON & $1(0,5 \%)$ \\
\hline 143. & HOPE IS A COMFORTER & $1(0,5 \%)$ \\
\hline 144. & TIME IS DEATH & $1(0,5 \%)$ \\
\hline 145. & LIFE IS A SEASON & $1(0,5 \%)$ \\
\hline 146. & LOVE IS A BIRD & $1(0,5 \%)$ \\
\hline 147. & $\begin{array}{l}\text { LOVE IS THE CROWN OF } \\
\text { THORNS }\end{array}$ & $1(0,5 \%)$ \\
\hline 148. & LIFE IS A CURSE & $1(0,5 \%)$ \\
\hline \multicolumn{3}{|c|}{$\begin{array}{c}\text { The total amount of the literary concepts }-184(100 \%) \text {. } \\
\text { Numbers } 1-2-13(7 \%) . \\
\text { Numbers }-3-18(40 \%) . \\
\text { Numbers } 19-148-131(71 \%) .\end{array}$} \\
\hline
\end{tabular}

The hierarchy of the conceptual metonymies reconstructed in the British poetry of the romantic period that fill the second additional circle and are represented in the following table (Table 3): 
Table 3

Conceptual metonymies reconstructed in the British poetry of the romantic period

\begin{tabular}{|c|c|c|}
\hline \multicolumn{2}{|c|}{ The hierarchy of the conceptual metonymies } & $\begin{array}{l}\text { The total amount } \\
\text { of the realization }\end{array}$ \\
\hline 1 & 2 & 3 \\
\hline 149. & NATURE STANDS FOR A PERSON & $1(2 \%)$ \\
\hline 150. & DEATH STANDS FOR A FRIEND & $1(2 \%)$ \\
\hline 151. & THE VOICE STANDS FOR THE HARP & $1(2 \%)$ \\
\hline 152. & LIFE STANDS FOR THE DAY & $1(2 \%)$ \\
\hline 153. & WINTER STANDS FOR DEATH & $1(2 \%)$ \\
\hline 154. & SPRING STANDS FOR REVIVAL & $1(2 \%)$ \\
\hline 155. & $\begin{array}{llll}\text { LOVE STANDS FOR A HUMAN } \\
\text { BEING (A PERSON) }\end{array}$ & $1(2 \%)$ \\
\hline 156. & THE FEARS STAND FOR AGE & $1(2 \%)$ \\
\hline 157. & THE TEARS STAND FOR AGE & $1(2 \%)$ \\
\hline 158. & $\begin{array}{l}\begin{array}{l}\text { DUST STANDS FOR THE POET } \\
\text { (A PERSON) }\end{array} \\
\end{array}$ & $1(2 \%)$ \\
\hline 159. & $\begin{array}{l}\text { A MONUMENT STANDS FOR A } \\
\text { POET (A PERSON) }\end{array}$ & $1(2 \%)$ \\
\hline 160. & $\begin{array}{l}\text { A ROSEBUD (A FLOWER) STANDS } \\
\text { FOR A GIRL (A PERSON) }\end{array}$ & $1(2 \%)$ \\
\hline 161. & $\begin{array}{llll}\text { FRIENDSHIP } & \text { STANDS } & \text { FOR } & \text { THE } \\
\text { GIFT } & & & \\
\end{array}$ & $1(2 \%)$ \\
\hline 162. & $\begin{array}{l}\text { THE FRIENDSHIP'S } \quad \text { HEART } \\
\text { STANDS FOR THE DEAREST GIFT } \\
\text { OF HEAVEN or } \\
\text { FRIENDSHIP STANDS FOR THE } \\
\text { GIFT OF HEAVEN }\end{array}$ & $1(2 \%)$ \\
\hline 163. & $\begin{array}{l}\text { THE VOLUMES (OF POETRY) } \\
\text { STAND FOR THE POET'S PRAYER }\end{array}$ & $1(2 \%)$ \\
\hline 164. & $\begin{array}{l}\text { GUARDIAN AND REWARD STAND } \\
\text { FOR PRAYS (POETRY) OF THE } \\
\text { POET }\end{array}$ & $1(2 \%)$ \\
\hline 165. & $\begin{array}{l}\text { A SHADOW STANDS FOR A } \\
\text { PERSON }\end{array}$ & $1(2 \%)$ \\
\hline 166. & $\begin{array}{l}\text { A MUSE STANDS FOR A FRIEND } \\
\text { (A PERSON) }\end{array}$ & $1(2 \%)$ \\
\hline
\end{tabular}


Continuation of table 3

\begin{tabular}{|c|c|c|}
\hline 1 & 2 & 3 \\
\hline 167. & $\begin{array}{llll}\text { AN ANGEL } & \text { STANDS } & \text { FOR } & \text { A } \\
\text { PERSON } & & & \\
\end{array}$ & $1(2 \%)$ \\
\hline 168. & $\begin{array}{l}\text { THE POET'S DARLING FLAME } \\
\text { STANDS FOR A PERSON (JESSY) }\end{array}$ & $1(2 \%)$ \\
\hline 169. & A NAME STANDS FOR A PERSON & $1(2 \%)$ \\
\hline 170. & $\begin{array}{l}\text { HANDS, VOICE, LOOKS, LIPS } \\
\text { STAND FOR A PERSON }\end{array}$ & $1(2 \%)$ \\
\hline 171. & A SHADOW STANDS FOR A CHILD & $1(2 \%)$ \\
\hline 172. & $\begin{array}{l}\text { THE SPIRIT STANDS FOR A SLAVE } \\
\text { (A PERSON) }\end{array}$ & $1(2 \%)$ \\
\hline 173. & $\begin{array}{llll}\text { THE SPOT STANDS } & \text { FOR } & \text { THE } \\
\text { PILGRIM'S SOUL } & & \\
\end{array}$ & $1(2 \%)$ \\
\hline 174. & $\begin{array}{l}\text { THE RED FLOWER STANDS FOR } \\
\text { LOVE }\end{array}$ & $1(2 \%)$ \\
\hline 175. & $\begin{array}{l}\text { THE DYING GLADIATOR STANDS } \\
\text { FOR LOVE }\end{array}$ & $1(2 \%)$ \\
\hline 176. & $\begin{array}{l}\text { THE SAD FLOWER STANDS FOR } \\
\text { LOVE }\end{array}$ & $1(2 \%)$ \\
\hline 177. & $\begin{array}{l}\text { A FLOWER STANDS } \\
\text { PERSON }\end{array}$ & $1(2 \%)$ \\
\hline 178. & A SPIRIT STANDS FOR A PERSON & $1(2 \%)$ \\
\hline 179. & $\begin{array}{l}\text { THE SCULPTURE STANDS FOR } \\
\text { THE MOTHER }\end{array}$ & $1(2 \%)$ \\
\hline 180. & $\begin{array}{llll}\text { THE SPIRIT STANDS } & \text { FOR } & \text { THE } \\
\text { DEAD CHILD } & & & \\
\end{array}$ & $1(2 \%)$ \\
\hline 181. & $\begin{array}{l}\text { THE HUMAN SOUL STANDS FOR } \\
\text { THE MAN }\end{array}$ & $1(2 \%)$ \\
\hline 182. & $\begin{array}{l}\begin{array}{l}\text { THE HEART STANDS FOR THE } \\
\text { MAN }\end{array} \\
\end{array}$ & $1(2 \%)$ \\
\hline 183. & $\begin{array}{l}\text { A NIGHTINGALE STANDS FOR } \\
\text { THE PERSON }\end{array}$ & $1(2 \%)$ \\
\hline 184. & $\begin{array}{l}\text { THE OAK STANDS FOR THE } \\
\text { GRAVE / FOR THE MONUMENT }\end{array}$ & $1(2 \%)$ \\
\hline 185. & THE VOICE STANDS FOR GOD & $1(2 \%)$ \\
\hline 186. & $\begin{array}{l}\text { THE FLOWER STANDS FOR THE } \\
\text { THOUGHT }\end{array}$ & $1(2 \%)$ \\
\hline 187. & BEES STAND FOR THE THOUGHTS & $1(2 \%)$ \\
\hline
\end{tabular}


End of table 3

\begin{tabular}{|c|l|c|}
\hline $\mathbf{1}$ & \multicolumn{1}{|c|}{$\mathbf{2}$} & $\mathbf{3}$ \\
\hline 188. & $\begin{array}{l}\text { A FLOWER STANDS FOR A } \\
\text { WOMAN }\end{array}$ & $1(2 \%)$ \\
\hline 189. & $\begin{array}{l}\text { A LITTLE BLACK THING STANDS } \\
\text { FOR THE BOY }\end{array}$ & $1(2 \%)$ \\
\hline 190. & $\begin{array}{l}\text { AN ANGEL STANDS FOR A } \\
\text { WOMAN }\end{array}$ & $1(2 \%)$ \\
\hline 191. & $\begin{array}{l}\text { THE IMMORTAL SPIRIT STANDS } \\
\text { FOR A PERSON (SHAKESPEARE) }\end{array}$ & $1(2 \%)$ \\
\hline 192. & $\begin{array}{l}\text { A PALE GHOST STANDS FOR THE } \\
\text { PERSON (A POET) }\end{array}$ & $1(2 \%)$ \\
\hline 193. & $\begin{array}{l}\text { VOICE STANDS FOR THE PERSON } \\
\text { A POET) }\end{array}$ & $1(2 \%)$ \\
\hline 194. & $\begin{array}{l}\text { THE FLOWER (THE ROSE) STANDS } \\
\text { FOR THE PERSON (A GIRL) }\end{array}$ & $1(2 \%)$ \\
\hline 195. & $\begin{array}{l}\text { THE BIRD (THE NIGHTINGALE) } \\
\text { STANDS FOR THE PERSON (A } \\
\text { MAN) }\end{array}$ & $1(2 \%)$ \\
\hline 196. & A GHOST STANDS FOR THE BOY & $1(2 \%)$ \\
\hline 197. & $\begin{array}{l}\text { A SAINT / AN ANGEL STAND FOR } \\
\text { A GIRL }\end{array}$ & $1(2 \%)$ \\
\hline 198. & A FACE STANDS FOR A PERSON & $1(2 \%)$ \\
\hline 199. & $\begin{array}{l}\text { SEVEN OR FIVE STAND FOR } \\
\text { SISTERS AND BROTHERS }\end{array}$ & $1(2 \%)$ \\
\hline & The total amount of the conceprual metonymies - 51. \\
\hline
\end{tabular}

The hierarchy of the conceptual metamorphosises (Москвичова 2015) reconstructed in the British poetry of the romantic period that fill the first main circle of the macrosegment of the fractal poetical model of the world are presented in the following table (number 200). The second additional circle is filled by the conceptual metaphors (numbers 201 202). The third additional circle is filled by the conceptual metaphors (numbers 203-223) (Table 4): 
Table 4

Conceptual metamorphosises reconstructed in the British poetry of the romantic period

\begin{tabular}{|c|c|c|}
\hline \multicolumn{2}{|r|}{$\begin{array}{c}\text { The hierarchy of the conceptual } \\
\text { metamorphosises }\end{array}$} & $\begin{array}{l}\text { The total amount of } \\
\text { the realization }(\%)\end{array}$ \\
\hline 1 & 2 & $\mathbf{3}$ \\
\hline 200. & $\begin{array}{l}\text { AN ALIVE PERSON TURNS INTO } \\
\text { A DEAD PERSON } \\
\text { DEATH } \\
\text { METAMORPHOSIS }\end{array}$ & $11(30 \%)$ \\
\hline 201. & $\begin{array}{l}\text { A YOUNG PERSON TURNS INTO } \\
\text { AN OLD PERSON } \\
\text { TIME CAUSES METAMORPHOSIS }\end{array}$ & $3(8 \%)$ \\
\hline 202. & $\begin{array}{l}\text { A PERSON IN LOVE TURNS INTO } \\
\text { A LONELY PERSON } \\
\text { LOVE } \\
\text { METAMORPHOSIS } \\
\end{array}$ & $2(5 \%)$ \\
\hline 203. & $\begin{array}{l}\text { AUTUMN TURNS INTO WINTER } \\
\text { NOVEMBER } \\
\text { METAMORPHOSIS OF AUTUMN } \\
\text { INTO WINTER }\end{array}$ & $1(3 \%)$ \\
\hline 204. & $\begin{array}{l}\text { PEOPLE TURN INTO MOURNING } \\
\text { PEOPLE } \\
\text { MAN'S INHUMANITY CAUSES } \\
\text { PEOPLE TO MOURN }\end{array}$ & $1(3 \%)$ \\
\hline 205. & $\begin{array}{l}\text { A PERSON TURNS INTO A } \\
\text { MOURNING PERSON } \\
\text { THE MAN HAS THE POWER AND } \\
\text { THE WILL TO CHANGE A MAN } \\
\text { INTO A MOURNING FELLOW }\end{array}$ & $1(3 \%)$ \\
\hline 206. & $\begin{array}{l}\text { WRETCHEDNESS OR VICE TURN } \\
\text { INTO RUIN } \\
\text { HEART } \\
\text { METAMORPHOSIS }\end{array}$ & $1(3 \%)$ \\
\hline 207. & $\begin{array}{l}\text { A DEAD PERSON TURNS INTO } \\
\text { AN ALIVE PERSON } \\
\text { A CHARM ON EARTH CAUSES } \\
\text { METAMORPHOSIS }\end{array}$ & $1(3 \%)$ \\
\hline
\end{tabular}


Continuation of table 4

\begin{tabular}{|c|c|c|}
\hline 1 & 2 & 3 \\
\hline 208. & $\begin{array}{l}\text { A DEAD PERSON TURNS INTO } \\
\text { AN ALIVE PERSON } \\
\text { ONE SERAPH'S } \\
\text { METAMORPHOSIS }\end{array}$ & $1(3 \%)$ \\
\hline 209. & $\begin{array}{l}\text { AN ILL PERSON TURNS INTO A } \\
\text { RECOVERED PERSON } \\
\text { A P PERSON } \\
\text { METAMORPHOSIS }\end{array}$ & $1(3 \%)$ \\
\hline 210. & $\begin{array}{l}\text { THE ROSY WINE BRINGS THE } \\
\text { DARLING FLAME (INSPIRATION) } \\
\text { TO THE POET } \\
\text { THE ROSY WINE CAUSES } \\
\text { METAMORPHOSIS }\end{array}$ & $1(3 \%)$ \\
\hline 211. & $\begin{array}{l}\text { A PERSON IS TURNED INTO A } \\
\text { BLEST PERSON WITH THE } \\
\text { BROKEN HEART } \\
\text { SUSPICION OR A PERSON (he) } \\
\text { CAUSES METAMORPHOSIS } \\
\end{array}$ & $1(3 \%)$ \\
\hline 212. & $\begin{array}{l}\text { A SWINE IS TURNED INTO A } \\
\text { PERSON } \\
\begin{array}{lll} & \\
\text { A PERSON } & \text { (he) } & \text { CAUSES } \\
\text { METAMORPHOSIS } & \end{array}\end{array}$ & $1(3 \%)$ \\
\hline 213. & $\begin{array}{l}\text { A DEAD BODY (SOUL) IS } \\
\text { TURNED INTO A RESURRECTED } \\
\text { BODY (SOUL) } \\
\text { GOD (Jesus Christ or He) CAUSES } \\
\text { METAMORPHOSIS }\end{array}$ & $1(3 \%)$ \\
\hline 214. & $\begin{array}{ll}\text { SOUL IS TURNED INTO A FOUL } \\
\text { FRIEND } \\
\text { MISERY } \\
\text { METAMORPHOSIS }\end{array}$ & $1(3 \%)$ \\
\hline 215. & $\begin{array}{l}\text { THE GAZER'S SPIRIT IS TURNED } \\
\text { INTO A STONE, } \\
\text { A VAPOUR OF THE AIR IS } \\
\text { TURNED INTO A MIRROR } \\
\text { THE MEDUSA CAUSES } \\
\text { METAMORPHOSIS }\end{array}$ & $1(3 \%)$ \\
\hline
\end{tabular}


End of table 4

\begin{tabular}{|c|c|c|}
\hline 1 & 2 & 3 \\
\hline 216. & 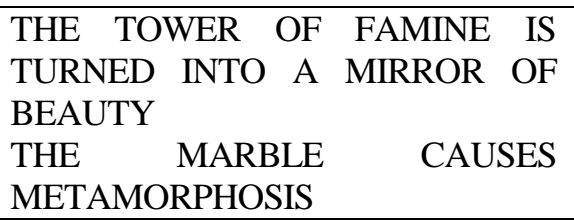 & $1(3 \%)$ \\
\hline 217. & $\begin{array}{l}\text { A PERSON IS TURNED INTO A } \\
\text { MATURE (AN OLD) PERSON } \\
\text { TIME CAUSES METAMORPHOSIS }\end{array}$ & $1(3 \%)$ \\
\hline 218. & $\begin{array}{l}\text { A CHILD TURNS INTO AN } \\
\text { ADULT PERSON } \\
\text { TIME CAUSES METAMORPHOSIS }\end{array}$ & $1(3 \%)$ \\
\hline 219. & $\begin{array}{lll}\text { AN ALIVE CHILD IS } & \text { TURNED } \\
\text { INTO A DEAD CHILD } & \\
\text { DEATH OR GOD } & \text { CAUSE } \\
\text { METAMORPHOSIS } & \\
\end{array}$ & $1(3 \%)$ \\
\hline 220. & $\begin{array}{lll}\text { SOULS TURN INTO } & \text { REVIVED } \\
\text { SOULS } & & \\
\text { REVIVAL } & \text { CAUSES } \\
\text { METAMORPHOSIS } & \\
\end{array}$ & $1(3 \%)$ \\
\hline 221. & $\begin{array}{l}\text { GOD TURNS INTO A CHILD } \\
\text { NAME } \\
\text { METAMORPHOSIS }\end{array}$ & $1(3 \%)$ \\
\hline 222. & $\begin{array}{l}\text { GOD TURNS INTO A PERSON } \\
\text { SORROW } \\
\text { METAMORPHOSIS }\end{array}$ & $1(3 \%)$ \\
\hline 223. & $\begin{array}{l}\text { DAY IS TURNED INTO NIGHT } \\
\text { TIME CAUSES METAMORPHOSIS }\end{array}$ & $1(3 \%)$ \\
\hline \multicolumn{3}{|c|}{$\begin{array}{l}\text { The total amount of the conceptual metamorphosises } \\
\text { \%). } \\
\text { Number } 200(29 \%) \text {. } \\
\text { Number } 201 \text { до } 202 \text { номерів - } 5(13 \%) \text {. } \\
\text { Numbers } 203 \text { до } 223 \text { номерів - } 22(58 \%) .\end{array}$} \\
\hline
\end{tabular}

The hierarchy of the conceptual oxymorons reconstructed in the British poetry of the romantic period that fill second additional circle is filled by the conceptual oxymorons (Table 5): 
Conceptual oxymorons reconstructed in the British poetry of the romantic period

\begin{tabular}{|l|l|l|}
\hline \multicolumn{2}{|c|}{$\begin{array}{c}\text { The hierarchy of the conceptual } \\
\text { oxymorons }\end{array}$} & $\begin{array}{c}\text { The total amount of } \\
\text { the realization }(\%)\end{array}$ \\
\hline 224. & DAY (LIFE) IS NOT A JOY & $1(17 \%)$ \\
\hline 225. & A BRITON IS NOT A SLAVE & $1(17 \%)$ \\
\hline 226. & BLOOM IS NOT IMMORTAL & $1(17 \%)$ \\
\hline 227. & JOY IS NOT GRIEF & $1(17 \%)$ \\
\hline 228. & PAIN IS NOT UNBELOVED & $1(17 \%)$ \\
\hline 229. & SILENCE IS NOT INVISIBLE & $1(17 \%)$ \\
\hline The total amount -6. \\
\hline
\end{tabular}

The correlation of the amount of the conceptual tropes in the macrosegment of the fractal poetical model of the world of the romantic period is summarized in the following table (Table 6):

The summarizing results

\begin{tabular}{|c|c|c|c|c|}
\cline { 2 - 5 } \multicolumn{1}{c|}{} & $\begin{array}{c}\text { Conceptual } \\
\text { metaphors } \\
(\%)\end{array}$ & $\begin{array}{c}\text { Conceptual } \\
\text { metonymies } \\
(\%)\end{array}$ & $\begin{array}{c}\text { Conceptual } \\
\text { metamorphosis } \\
\text { es }(\%)\end{array}$ & $\begin{array}{c}\text { Comceptual } \\
\text { oxymorons } \\
(\%)\end{array}$ \\
\hline $\begin{array}{c}\text { The total } \\
\text { amount of } \\
\text { the } \\
\text { conceptual } \\
\text { tropes }(\%)\end{array}$ & $184(66 \%)$ & $51(18 \%)$ & $38(14 \%)$ & $6(2 \%)$ \\
\hline $\begin{array}{c}279 \\
(100 \%)\end{array}$ & \multicolumn{3}{|c}{} \\
\hline
\end{tabular}

\section{CONCLUSIONS}

The fractal poetical model of the world is modelled by us on the basis of the British poetry of the XIX $-\mathrm{XXI}^{\text {st }}$ centuries and our investigation can be perspective because depending on the material of the investigation the fractal model of the world can be constructed not only in the poetry but in the narratology. Thus, the fractal model of the world may be mythological and religious (on the basis of religious and mythological texts), utopian (on the basis of the political texts), historical and philosophical (on the basis of historical and philosophical texts or texts 
that reflect the historical personality/personalities), futrological (on the basis of the texts of the fantasy genre).

Proposed fractal modelling may be perspective in the investigation of the literary work of a poet, an author, an epoch or poets, authors or different cultural and historical periods. We assume that the fractal model of the world may be semiotical including symbols that can be individual and authors, emphatic, eidetic. In the mathematics and in the geometry, in the existing fractal theory, are identified various types of fractals. It is proved that structures the algorithm of the modelling of which is changed spontaneously are superfractals. Multifractals are the complicated fractal structures that consist from several fractal structures. Allatorial fractals fractals in which the smallest outer influence or the outer fluctuations change the form of the whole fractal ${ }^{13}$.

In the linguistic perspective we consider that that the linguistic model may be superfractal segments of which are changed with the integration to the investigation of the text the comparative analysis. The multifractal is the linguistic model that is added by the other linguistic aspect (for example, the combination of the linguistic, the cognitive and the semiotic aspects of the investigation of the texts). The allatorial fractal linguistic model is the model segments of which are changed while the incorporation the new results of the investigation of the text unidentified by the predecessors (e.g., (Fig. 15)):

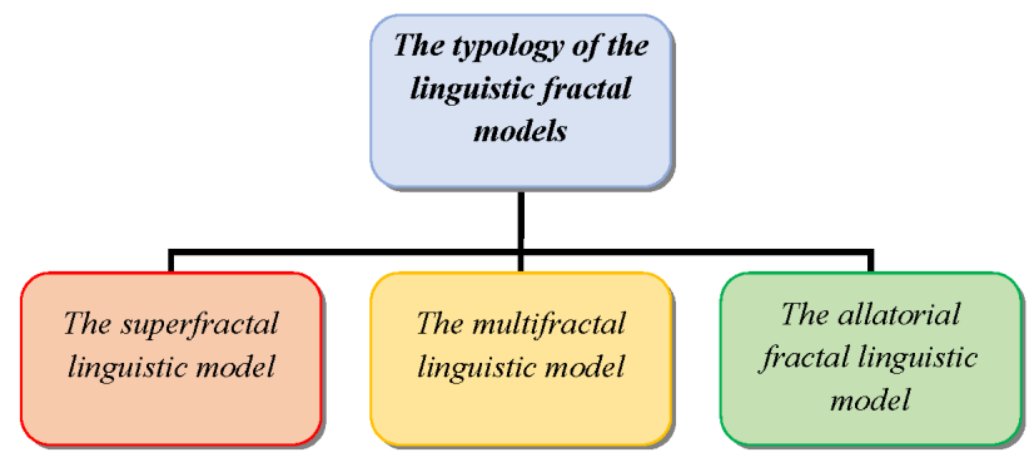

Fig. 15. The proposed typology of the linguistic fractal models

${ }^{13}$ Demenok S. L. (2018) Prosto fraktal. [The Simple Fractal]. SanktPeterburg : Strata. (in Russian) 
The proposed by us methodology of the modelling of the fractal poetical model of the world opens the new paradigm in the modern cognitive linguistics and the cognitive poetics - the cognitive graphics or the cognitive fractal graphics that comprises the combination of the cognitive linguistics, the cognitive poetics, the mathematics, the fractal geometry, the theory of systems, the synergetics. Modelled by us the fractal poetical model of the world is characterized not by the rhizome but the strictly determined structure because the fractal is characterized by the strictly determined structure and consists from the elements of the reductions scale that are self-similar and are excelled by the hierarchical organization, by the recursiveness and by the iteration because the process of the fractal modelling is determined by the multifaceted repetition of the analogical mathematical operations - iterations that are recursive, the final element of the fractal is the beginning of the new element - the recursive. Fractal iterations in our process of the design of the fractal poetical model of the world are the linguistic and the cognitive operations and mechanisms that help the linguists to identify literary concepts and to reconstruct conceptual tropes in the text. Recursiveness is the ability of the micro-segment of the fractal poetical model of the world to be transformed into the frame mode, and the macro-segment - into the integrated mode of emergent conceptual blends. The cognitive fractal graphics is proved in the scientific research by the computer design of the fractal poetical model of the world on the basis of the fractal modelling in the mathematics, in the fractal geometry and in the computer graphics.

\section{SUMMARY}

The article is dedicated to the investigation of the specificity of the reproduction of the reality in the fractal poetical model of the world on the basis of the British poetry of the XIX $-\mathrm{XXI}^{\text {st }}$ centuries with the help of the linguistic, the poetical analysis of the lexical and the semantic tropes as the verbal means of actualization of cognitive processes of the formation of the fractal poetical model of the world and the outlining of the axiological sense that is specific for the cognitive style of poets of the British romantic, modern and postmodern periods by means of the linguistic, the cognitive, the poetic analyses of the above mentioned tropes. The analyses comprises the usage of the cognitive and the discourse strategies of the interpretation of the deepest sense of the fractal poetical model of the world, such as: the reconstruction of the axiological literary concepts as elements of the fractal poetical model of the world, the modelling of the conceptual tropes as the cognitive basis of the 
formation and the designing of the fractal poetical model of the world and the modelling of the conceptual blends and frames as emergent cognitive structures of the embodied understanding in the poetics of the British romantic, modern and postmodern periods.

\section{REFERENCES}

1. Bystrov Ja. V. (2016) Bioghrafichnyj naratyv $u$ linghvokoghnityvnomu vymiri (na materiali anghlomovnoji prozy XX pochatku XXI stolitj) [The Biographical Narrative in the Linguistic and the Cognitive Aspects (on the basis of the English Prose of the $X X^{\text {th }}-$ the beginning of the XXI $I^{\text {st }}$ Centuries] : dys. ... d-ra fil. nauk : 10.02.04 / Kyjivsjkyj nac. linghvistychnyj un-t. Kyjiv. (in Ukrainian)

2. Demenok S. L. (2018) Prosto fraktal. [The Simple Fractal]. Sankt-Peterburg : Strata. (in Russian)

3. Demenok S. L. (2018) Superfraktal. [The Superfractal]. SanktPeterburg : Strata. (in Russian)

4. Moskvychova O. A. (2015) Evoljucija metamorfozy $v$ anghlijsjkomu poetychnomu myslenni : monoghrafija. [The Evolution of Metamorphosis in the English Poetry : the Monograph]. Kherson : Ajlant. (in Ukrainian)

5. Blake W. (2019) The Selected Poems. London : Wordsworth Poetry Library. (in English)

6. Mandelbrot B. B. (1982) The Fractal Geometry of Nature. New York : W. H. Freemanand Company. (in English)

7. Nikonova V., Boyko Y. (2019) Gender-specific emotivity of Victorian female prose from a multidimensional perspective. In Lege artis. Language yesterday, today, tomorrow. Vol. IV (1), pp. 47-82. (in English)

\section{Information about the author: Oksana Moskvichova,}

Candidate of Philological Sciences, Associate Professor, Associate Professor at the Department of the English Language and the Methodology of Teaching, Doctoral Student,

Kherson State University

27, University str., Kherson, 73000, Ukraine ORCID ID: https://orcid.org/0000-0001-7678-5834 